\title{
An Assessment of the Occurrence of Selected Virulence and Antibiotic Resistance Genes in Bacteria of the Genus Campylobacter Collected from Horses
}

https://doi.org/10.1515/ovs-2020-0100

received Mar 17, 2020; accepted Apr 30, 2020

\begin{abstract}
The aim of the study was to determine the frequency of Campylobacter spp. bacteria occurrence in female Hutsul horses, and the presence of selected virulence genes and resistance to antibiotics among the isolates obtained in the experiment. One hundred $(n=100)$ healthy mares were tested. Campylobacter spp. bacteria were found in $9(n=9)$ animals, $89 \%(n=8)$ of which were described as $C$. jejuni. There were no $C$. coli or $C$. lari found. Analyses of $C$. jejuni isolates revealed the presence of selected virulence genes in the following order: $\operatorname{cadF}$ ( $n$ $=5), c d t A(n=1)$ and $\operatorname{cdtB}(n=3)$. The following antibiotics were used to test the antibiotic resistance of the bacteria: ampicillin (AMP), ciprofloxacin (CIP), erythromycin (E), gentamicin (GE), meropenem (MEM) and tetracycline (TE). C. jejuni were completely sensitive to ciprofloxacin, gentamicin, meropenem, and tetracycline.
\end{abstract}

Keywords: Campylobacter, drug resistance, horses, virulence genes

\section{Introduction}

Thermotolerant bacteria of the Campylobacter genus (mainly Campylobacter jejuni and Campylobacter coli) are part of the natural intestinal flora of birds and mammals. They are also commonly found in water and soil contaminated with animal faeces [1]. Contact with faeces or with a sick animal and failure to comply with basic

\footnotetext{
*Corresponding author: Marek Selwet, Department of General and Environmental Microbiology, Poznań University of Life Sciences, ul. Szydłowska 28, 60-637 Poznań, Poland; Tel.: +48 6184667 21; E-mail: marek.selwet@gmail.com (M. Selwet).
}

rules of hygiene may cause campylobacteriosis in humans [2]. Since 2005 the incidence of this disease in humans has increased in Europe. In 2015 the overall incidence of infections in the European Union was 65.5 cases per 100,000 inhabitants [3]. Horse breeders are an occupational group that may be at risk of Campylobacter infections. Diarrhoea in horses is often underestimated because it is treated as a side effect of changing the feed. Only recently infectious factors that may cause ailments in horses have been taken into consideration. Samples of horse faeces have been tested for the presence of eggs and larvae of nematodes, of Clostridium toxins, enteropathogens, as well as blood and sand. Immunological tests are also used to analyse samples of faeces. The fact that Campylobacter bacteria may cause diarrhoea in horses is becoming increasingly important [4]. The course of diarrhoea is usually mild in foals. It is related to a change in the intestinal biota of foals that begin to consume roughage and grain. Diarrhoea may be more severe if it is caused by bacteria. Then horses tend to be listless, lack appetite, and their body temperature is often elevated. Their faeces are watery, with a pungent and unpleasant smell. In such cases it is necessary to apply intensive antibacterial treatment, supplement the amount of lost fluids, compensate for disordered electrolyte balance and to ensure veterinary care [5].

Current studies are a continuation of earlier research conducted by the same research laboratory on mares (different races) from the Wielkopolskie Voivodeship. The difference in the conducted research is the method of animal selection (a primitive local race was chosen). Hucul race is one of the oldest primitive breeds described in Poland. Characteristics of genetic variability of local breeds, i.a. Hucul horse, is substantial as one of the global priorities of scientific research to maintain the genetic resource.

The aim of the study was: (i) to determine the frequency of Campylobacter bacilli occurrence in swabs 
with horse faeces; (ii) identify bacterial species within the isolates of the Campylobacter genus; (iii) identify selected virulence genes in the isolated bacterial strains; (iv) identify the genes affecting the occurrence of cytolethal distending toxin (CDT); (v) determine the resistance of Campylobacter bacteria to selected antibiotics.

\section{Materials and methods}

\subsection{Sampling}

Swab samples collected per rectum (swabs. Sterile, product No. 300295, Deltalab, Spain) from $100(n=100)$ healthy Hucul mares aged up to 4 years were used as a study material. The animals came from a stable in Podkarpackie Voivodeship. The samples were stored at $4^{\circ} \mathrm{C}$ and transported to a laboratory not later than 6 hours after being collected.

Ethical approval: The research related to animals use has been complied with all the relevant national regulations and institutional policies for the care and use of animals.

\subsection{Isolation and identification of Campylo- bacter spp. from swab samples}

The swab specimens were initially placed in $3 \mathrm{ml}$ of Preston Broth No. 2 selective medium (product No. CM067, Lysed Horse Blood product No. SR0048, Preston Campylobacter Selective Supplement product No. SR0117 and Campylobacter Growth Supplement product No. SR0232, OXOID). Next, they were incubated in a CampyGen anaerostat (product No. CN0025, OXOID) at $41.5^{\circ} \mathrm{C}$ for $24 \mathrm{~h}$ $\left(5 \% \mathrm{O}_{2}, 10 \% \mathrm{CO}_{2}, 85 \% \mathrm{~N}_{2}\right)$. After incubation the bacterial cultures were centrifuged $(4,000 \times \mathrm{g} / 15 \mathrm{~min})$. The supernatant was decanted and the sediment was added to $1 \mathrm{ml}$ of Karmali medium. $200 \mu \mathrm{l}$ of the suspension was spread with a cell spreader on a Karmali selective medium (product No. CM0935, OXOID) and it was incubated in an anaerostat at $41.5^{\circ} \mathrm{C}$ for $48 \mathrm{~h}$. An $\mathrm{API} ®$ Campy biochemical test product No. 20800 (BIOMÉRIEUX) was applied to identify the presence of Campylobacter spp. The bacterial cells were identified through observation of their morphological traits and mobility (Axio Imager. A2 microscope, ZEISS). Next, the following tests were applied: oxidase (OXI detection strip, product No. 2001, DIAGNOSTICS Inc., Slovakia), catalase (API® ID colour catalase, product No. 55561, BIOMÉRIEUX) and the ability to hydrolyse hippurate and indoxyl acetate (HIP), product
No. 2006 and HIP reagent, product No. 3006; INDOXYL, product No. 2007, DIAGNOSTICS Inc., Slovakia). A confirmatory test was conducted on a selective mCCDA medium (OXOID) after incubation at $41.5^{\circ} \mathrm{C}$ for $48 \mathrm{~h}$ were the grown colonies were counted. Campylobacter spp. was distinguished from other Gram-negative bacteria with the O.B.I.S. Campy test (product No. ID0800M, OXOID). Realtime PCR (BIORAD) and the BAX® System Real-Time PCR Assay for Campylobacter (product No. D12683449 KIT2018, HYGIENA) were used for identification of the species.

\subsection{Identification of genes determining CDT occurrence by means of multiplex PCR}

The $c d t A, c d t B$, and $c d t C$ genes were identified using the primers shown in Table 1 . A reaction mixture $(25 \mu \mathrm{l}$ total volume) was composed of: $2.5 \mu \mathrm{l} 10 \mathrm{x}$ PCR buffer, 6 x $1 \mu \mathrm{l}$ primers (5pM), $1 \mu \mathrm{ldNTP}(2.5 \mathrm{mM}), 0.2 \mu \mathrm{l} \mathrm{Taq}$ polymerase, $1.8 \mu \mathrm{l} \mathrm{DNA}$, and $13.5 \mu \mathrm{l}$ water. The reaction was conducted under the following conditions: pre-denaturation at $94^{\circ} \mathrm{C}$ for $2 \mathrm{~min}$ followed by 30 cycles of denaturation at $94^{\circ} \mathrm{C}$ for $0.5 \mathrm{~min}$, annealing at $50^{\circ} \mathrm{C}$ for $0.5 \mathrm{~min}$ and extension at $72^{\circ} \mathrm{C}$ for $1 \mathrm{~min}$, and final step at $72^{\circ} \mathrm{C}$ for $5 \mathrm{~min}$. The resulting products were analysed by electrophoresis in $1.5 \%$ agarose gel.

Table 1 Sequences of the primers used to detect the genes $c d t A$, $c d t B, c d t C$

\begin{tabular}{|c|c|c|c|}
\hline Primer & Sequences $5^{\prime} \rightarrow 3^{\prime}$ & $\begin{array}{l}\text { Product } \\
\text { size (bp) }\end{array}$ & References \\
\hline$c d t A-\mathrm{F}$ & CTA TTA CTC CTA TTA CCC CAC C & \multirow{2}{*}{422} & \multirow{6}{*}{ [6] } \\
\hline$c d t A-\mathrm{R}$ & AAT TTG AAC CGC TGT ATT GCT C & & \\
\hline$c d t B-\mathrm{F}$ & AGG AAC TTT ACC AAG AAC AGC C & \multirow{2}{*}{531} & \\
\hline$c d t B-\mathrm{R}$ & GGT GGA GTA TAG GTT TGT TGT C & & \\
\hline$c d t C-\mathrm{F}$ & ACT CCT ACT GGA GAT TTG AAA G & \multirow{2}{*}{339} & \\
\hline$c d t C-\mathrm{R}$ & CAC AGC TGA AGT TGT TGT TGG C & & \\
\hline
\end{tabular}

\subsection{Identification of virulence genes}

The cadF, flaA, and iam genes were identified with the primers listed in Table 2. The total volume of the reaction mixture was $25 \mu \mathrm{l}$. It was composed of: $2.5 \mu \mathrm{l} 10$ x PCR buffer, $2.5 \mu \mathrm{lgCl}_{2}(25 \mathrm{mM}), 1 \mu \mathrm{l}$ dNTP (2.5 mM), $1 \mu \mathrm{l}$ primers (5pM), $0.2 \mu \mathrm{l}$ (1U ) U Taq DNA polymerase (Promega Corporation), $2 \mu$ DNA, and $15.5 \mu$ l water. The reaction was conducted under the following conditions: pre-denaturation at $94^{\circ} \mathrm{C}$ for $1 \mathrm{~min}$ followed by 30 cycles, of denaturation at $94^{\circ} \mathrm{C}$ for $0.5 \mathrm{~min}$, annealing $45^{\circ} \mathrm{C}$ for 1 min and extension at $72^{\circ} \mathrm{C}$ for $2 \mathrm{~min}$, and final step at 
$72^{\circ} \mathrm{C}$ for $5 \mathrm{~min}$. The resulting products were analysed by electrophoresis in $1.5 \%$ agarose gel.

Table 2 Sequences of the primers used to detect the genes $c a d F$, flaA, iam

\begin{tabular}{|c|c|c|c|}
\hline Primer & Sequences 5' $\rightarrow 3^{\prime}$ & $\begin{array}{l}\text { Product } \\
\text { size (bp) }\end{array}$ & References \\
\hline cad F-F & TGGAGGGTAATTTAGATATTG & \multirow{2}{*}{400} & \multirow{2}{*}{ [7] } \\
\hline cad F-R & СTAATACCTAAAGTTGAAAC & & \\
\hline fla $A-\mathrm{F}$ & GGATTTCGTATTAACACAAATGGTGC & \multirow{2}{*}{1728} & \multirow{2}{*}{ [8] } \\
\hline fla $A-\mathrm{R}$ & CTGTAGTAATCTTAAAACATTTTG & & \\
\hline iam- $\mathrm{F}$ & GCGCAAAATATTATCACCC & \multirow{2}{*}{518} & \multirow{2}{*}{ [9] } \\
\hline$i a m-\mathrm{R}$ & TTCACGACTACTATGCGG & & \\
\hline
\end{tabular}

\subsection{Assessment of sensitivity to antibiotics}

The Kirby-Bauer disc diffusion method was used to test the isolated bacterial strains of the genus Campylobacter for antibiotic susceptibility. The method recommended by the EUCAST [10] standards of Disc Diffusion Method for Antimicrobial Susceptibility Testing and the National Committee for Clinical Laboratory Standards (NCCLS) was used. Bacterial isolates were grown in LB Broth medium (Merck) for $24 \mathrm{~h}$ incubation at $37^{\circ} \mathrm{C}$. Subsequently, bacterial culture was diluted to a density of 0.5 on the McFarland scale. The suspension was diluted again at a 1:10 ratio and a $100 \mu \mathrm{l}$ of bacterial suspension was spread on a surface of Mueller-Hinton agar medium (Merck) supplemented with $20 \mathrm{mg} / \mathrm{L}$ ß-NAD. Next, antibiotic-impregnated discs were applied: ampicillin (AMP; $25 \mu \mathrm{g} / \mathrm{disc}$ ), ciprofloxacin (CIP; $5 \mu \mathrm{g} /$ disc), erythromycin (E; $15 \mu \mathrm{g} /$ disc), gentamycin (GE; $10 \mu \mathrm{g} / \mathrm{disc}$ ), meropenem (MEM; $10 \mu \mathrm{g} /$ disc), tetracycline (TE; $30 \mu \mathrm{g} / \mathrm{disc}$ ). The inoculated plates were incubated at $41 \pm 1^{\circ} \mathrm{C}$ for $24 \mathrm{~h}$. Campylobacter jejuni ATCC 33291 and Campylobacter coli ATCC 33559 (DSMZ, Germany) were used as reference strains in the study.

\section{Results and discussion}

The fact is that Campylobacter spp. is very rarely found in horses. So far there have been few scientific publications focusing on the identification of these bacteria in Equidae. However there is an increasing number of opinions that the occurrence of Campylobacter bacilli should be routinely monitored because these bacteria might cause chronic diarrhoea in horses [4]. Campylobacter bacilli were found in $9(n=9)$ out of $100(n=100)$ mares, which means that $9 \%$ of the test samples were positive. Molecular biology techniques were used for further identification of the isolates. C. jejuni was found in $8(n=8 ; 89 \%)$ mares, but $C$. coli and $C$. lari were not identified. The need for modern PCR methods is indicated by Boer et al. [11]. The authors evaluated the use of real-time PCR for the detection of Campylobacter spp. and selected genes characteristic of specific Campylobacter species. The results obtained by the authors indicate that the generic 16S Campylobacter PCR detection is equally reliable but much faster than detection by means of culturing. Moreover, PCR detection targeting the genes provide the possibility of $C$. jejuni and $C$. coli species discrimination. In addition, the results obtained by these authors through the use of the PCR method suggest the presence of alternative species of Campylobacter in the samples tested. The presence of Campylobacter bacteria in the horses was also reported by other authors. The frequency of their occurrence was diversified. Komba et al. [12] detected these bacteria in $60 \%$ of the horses, Baserisalehi et al. [13] in 27\%, whereas Moriarty et al. [14] in 3\% of test horses. In study of Moriarty et al. [14] all Campylobacter isolates were identified as $C$. jejuni. It is also noteworthy that it was the first report on the presence of Campylobacter spp. in healthy horses in New Zealand [14]. In the present study, eight isolates of $C$. jejuni were used in further tests to identify selected virulence genes. The $c a d F$ gene was identified in 5 isolates ( $56 \%$ of the samples). We previously observed a higher incidence of this gene in mares from the Wielkopolska region, namely $62.5 \%(n=10 / 16)[5]$. The protein encoded by this gene plays an important role in the pathogenesis of Campylobacter bacteria. It is responsible for binding enterocytes in the intestinal epithelium to fibronectin, thus internalising bacterial cells $[15,16]$. Neither the flaA nor the iam gene was found in any of the isolates (Table 3). The flaA gene is responsible for the formation of flagellin $\mathrm{A}$ (FlaA) protein which is one of the two subunits of Campylobacter flagella. The iam gene encodes the invasion associated marker (IAM) and survival in host cells [9, 17]. At the next stage of the research, eight $C$. jejuni isolates were analysed for the presence of the $c d t A, c d t B$ and $c d t C$ genes responsible for the occurrence of cytolethal distending toxin (CDT). The $c d t B$ gene was found in 3 isolates (33\%), the $c d t A$ gene in 1 isolate (11\%), whereas the $c d t C$ gene was not detected (Table 3). We examined mares in the Wielkopolska region for occurrence of Campylobacter bacteria and found that $37 \%$ of the isolates $(n=6 / 16)$ had cdtB gene [5] and did not find the $c d t A$ or $c d t C$ gene among test isolates. These genes are commonly found in poultry, cats, dogs and piglets [6]. However, there have been very few studies reporting their presence in Campylobacter isolates from horses. Therefore, our research may be an important element providing information on the occurrence of these genes in horses. It may help to answer the question whether horses' intestinal biota might be a potential reservoir of Campylobacter spp. 
isolates, which are pathogenic to humans and animals. The results of the study on antibiotic resistance of Campylobacter isolates vary between laboratories. EUCAST recommends [10] that ciprofloxacin (CIP), erythromycin (E) and tetracycline (TE) should be used in antibiotic resistance tests of Campylobacter bacteria. It is widely known that macrolides such as erythromycin can be used to treat Campylobacter spp. infections in humans and animals. However, strains isolated from animals may exhibit acquired cross-resistance to this group of antibiotics. Our tests of antibiotic resistance showed that $9(100 \%)$ isolates were sensitive to selected antibiotics: ciprofloxacin (CIP) belonging to quinolones (it is important to note that mutation in the gyrA gene may result in Campylobacter spp. resistance to this antibiotic), gentamycin (GE), meropenem (MEM) and tetracycline (TE) (Table 4). The effectiveness of gentamicin against campylobacteriosis was reported by Wasyl and Osek [18] and Rzewuska et al. [19]. We previously reported high susceptibility to tetracycline [5] and found one of 16 isolates resistant to this antibiotic. In our study 7 isolates (78\%) were resistant to ampicillin (AMP) and 4 isolates $(44 \%)$ were resistant to erythromycin (E). The continuous growth of Campylobacter spp. resistance to an increasing number of antimicrobial agents should be a matter of concern. Therefore, it is important to continue searching for new substances against Campylobacter spp. The results of our research showed that meropenem, which is used against Salmonella bacilli, proved to be an effective antagonist of Campylobacter spp. These findings were also supported by Wieczorek and Osek [2] and Karikari et al. [20] who reported the use of this antibiotic against intestinal bacteria in their studies

Table 3 Occurrence of $c a d F$, flaA, iam, $c d t A, c d t B, c d t C$ genes in $C$. jejun

\begin{tabular}{ccccccc}
\hline \multirow{2}{*}{ Isolates } & \multicolumn{6}{c}{ Genes } \\
\cline { 2 - 7 } & cadF & flaA & iam & cdtA & $c d t B$ & $c d t C$ \\
\hline 1 & + & - & - & - & + & - \\
\hline 2 & - & - & - & - & - & - \\
\hline 3 & + & - & - & - & - & - \\
\hline 4 & + & - & - & - & + & - \\
\hline 5 & - & - & - & + & - & - \\
\hline 6 & + & - & - & - & - & - \\
\hline 7 & - & - & - & - & - & - \\
\hline 8 & + & - & - & - & + & - \\
\hline 9 & - & - & - & - & - & - \\
\hline
\end{tabular}

Explanation: +; gene presence, -; no gene.
Table 4 Resistance of $C$. jejuni isolates to antibiotics

\begin{tabular}{ccccccc}
\hline \multirow{2}{*}{ Isolates } & \multicolumn{7}{c}{ Antibiotics } \\
\cline { 2 - 7 } & AMP & CIP & E & GE & MEM & TE \\
\hline 1 & + & - & + & - & - & - \\
\hline 2 & + & - & - & - & - & - \\
\hline 3 & + & - & + & - & - & - \\
\hline 4 & + & - & - & - & - & - \\
\hline 5 & + & - & - & - & - & - \\
\hline 6 & + & - & + & - & - & - \\
\hline 7 & - & - & + & - & - & - \\
\hline 8 & + & - & - & - & - & - \\
\hline 9 & - & - & - & - & - & - \\
\hline C. jejuni & + & - & - & - & - & - \\
ATCC 33291 & & & & & & \\
\hline
\end{tabular}

Explanation: +; resistant, -; susceptible. AMP; ampicillin, CIP; ciprofloxacin, E; erythromycin, GE; gentamicin, MEM; meropenem, TE; tetracycline.

\section{Conclusions}

In the nearest future it will be necessary to increase the number of investigations and scientific studies on the occurrence of Campylobacter bacteria and the presence of virulence genes in these bacteria isolated from horses. It is particularly important to use more and more modern methods of isolation and identification of various species of Campylobacter bacilli in this group of animals. Traditional, well-developed ways pathogen identification often requires a lot of time and work, and selection of qualified experienced personnel. In recent years, analytical methods have been enriched with modern and rapid molecular tests. They have wide use in diagnostic due to high sensitivity and specificity and significantly accelerating the testing procedure. It is satisfactory that the incidence of virulence genes and the genes responsible for the occurrence of CDT was not high in the horses tested in our research. Although the presence of Campylobacter spp. is not synonymous with infection, the clinical significance and the pathogenicity of these bacteria has not been fully investigated and requires further research. It is necessary to conduct further research on these bacteria as they are potential risk factors that will help to better understand the epidemiology of Campylobacter spp. It is also necessary to conduct further research to emphasise the danger of unreasonable use of antibiotics in both human and animal therapy.

Conflict of interest: Author states no conflict of interest. 


\section{References}

[1] Selwet M, Galbas M. Monitoring of selected genes in Campylobacter jejuni and Campylobacter coli isolates from domestic animals. B Vet I Pulawy. 2012;56(3):283-6.

[2] Wieczorek K, Osek J. Antimicrobial resistance of Campylobacter and Salmonella strains isolated in the European Union Member States in 2015. Zycie Wet. 2017;92:373-5.

[3] Pölzer T, Stüger HP, Lassing H. Prevalence of most common human pathogenic Campylobacter spp. in dogs and cats in Styria, Austria. Vet Med Sci. 2018;4:115-125. http://doi: https:// doi.org/10.1002/vms3.93.

[4] Hurcombe SD, Fox JG, Kohn CW. Isolation of Campylobacter fetus subspecies fetus in a two-year-old quarterhorse with chronic diarrhea of an undetermined etiology. J Vet Diagn Invest. 2009 Mar;21(2):266-9.

[5] Selwet M, Galbas M. Assessment of the occurrence of selected virulence genes, and antibiotic resistance of Campylobacter jejuni isolates collected from horses. Wiad Zootech. 2019;3:55-62.

[6] Carvalho AF, Silva DM, Azevedo SS, Piatti RM, Genovez ME, Scarcelli E. 2010. Detecção dos genes da toxina citoletal distensiva em estirpes de Campylobacter jejuni isoladas de carcaças de frangos. Arq Bras Med Vet Zoo. 2010;62:1054-1061. http://doi: org/https://doi.org/10.1590/ S0102-09352010000500006.

[7] Konkel ME, Gray SA, Kim BJ, Garvis SG, Yoon J. Identification of the enteropathogens Campylobacter jejuni and Campylobacter coli based on the cadF virulence gene and its product. J Clin Microbiol. 1999 Mar;37(3):510-7.

[8] Nachamkin I, Bohachick K, Patton CM. Flagellin gene typing of Campylobacter jejuni by restriction fragment length polymorphism analysis. J Clin Microbiol. 1993 Jun;31(6):1531-6.

[9] Carvalho AC, Ruiz-Palacios GM, Ramos-Cervantes P, Cervantes LE, Jiang X, Pickering LK. 2001. Molecular characterization of invasive and noninvasive Campylobacter jejuni and Campylobacter coli isolates. J Clin Microbiol. 2001;39:1353-1359. http://doi: https://doi.org/10.1128/ JCM.39.4.1353-1359.2001.
[10] EUCAST Disk Diffusion Method for Antimicrobial Susceptibility Testing. 2020 www.eucast.org

[11] de Boer P, Rahaoui H, Leer RJ, Montijn RC, van der Vossen JM. Real-time PCR detection of Campylobacter spp.: A comparison to classic culturing and enrichment. Food Microbiol. 2015 Oct;51:96-100.

[12] Komba EV, Mdegela RH, Msoffe PL, Matowo Makori DE, Maro J. Occurrence, species distribution and antimicrobial resistance of Campylobacter thermophilic isolates from farm and laboratory animals in Morogoro, Tanzania. Vet World. 2014;7:559-65.

[13] Baserisalehi M, Bahador N, Kapadnis BP. Isolation and characterization of Campylobacter spp. from domestic animals and poultry in south of Iran. Pak J Biol Sci. 2007; 10:1519-1524; http://doi: https://doi.org/10.3923/pjbs.2007.1519.1524.

[14] Moriarty EM, Downing M, Bellamy J, Gilpin BJ. Concentrations of faecal coliforms, Escherichia coli, enterococci and Campylobacter spp. in equine faeces. New Zeland Vet J. 2015; 63:104-109; http://doi: https://doi.org/10.1080/00480169.2 014.952789 .

[15] Andrzejewska M, Szczepańska B, Śpica D, Klawe JJ. Prevalence of pathogenic genes of Campylobacter jejuni and Campylobacter coli isolated from environmental material. Environ Med. 2010;13:57-62.

[16] Szewczyk R, Wieczorek K, Osek J. Molekularne mechanizmy chorobotwórczości termotolerancyjnych Campylobacter. Med Weter. 2011;67:725-32.

[17] Rokosz-Chudziak N, Rastawicki W. [Selected mechanisms of pathogenicity of Campylobacter jejuni]. Med Dosw Mikrobiol. 2014;66(1):47-58.

[18] Wasyl D, Osek J. Monitoring of antimicrobial resistance in Salmonella and Campylobacter strains isolated from animals. Zycie Wet. 2008;3:107-10.

[19] Rzewuska K, Korsak D, Maćkiw E. [Antibiotic resistance of bacteria Campylobacter sp]. Przegl Epidemiol. 2010;64(1):63-8.

[20] Karikari AB, Obiri-Danso K, Frimpong EH, Krogfelt KA. Antibiotic resistance of Campylobacter recovered from faeces and carcasses of healthy livestock. Bio Med Res Int. Article ID 4091856, 9 pages. 2017; http://doi.org/https://doi. org/10.1155/2017/4091856. 